\title{
PENGENALAN PAJAK SEJAK DINI PADA SISWA SMP MELALUI MEDIA INTERAKTIF BERBASIS MACROMEDIA FLASH DI KABUPATEN SIDOARJO
}

\author{
Yuni Purnamasari ${ }^{1}$ dan Muhafidhah Novie ${ }^{2}$ \\ Universitas Nahdlatul Ulama Sidoarjo \\ yunipurnama677@gmail.com ${ }^{1)}$, Muhafidhah@gmail.com ${ }^{2)}$
}

\begin{abstract}
This research is aimed to provide a knowledge of taxes from an early age to junior high school students. Sampel of this research is consists of three schools, namely: (1) SMP N 1 Sidoarjo, (2) SMP N 2 Sidaorjo, and (3) SMP Islam Sidoarjo. The total of sampel this research was 89 students. The study was carried out by providing training to participants using interactive's media based macromedia flash. Tax interactive media about: tax and simulations of calculation tax. The research method consists of: (1) media design, (2) field survey, (3) coordination to school, (4) socialization, (5) training provision, and (6) student response questionnaire. Data collection tools consist of students questionnaire sheets. The result of the research shows that there was an increase in students' knowledge about taxes before and after being given training. Students of SMP N 1 sidoarjo there was an increase from 40.5 to 78 after being given training. In SMPN 2 Sidoarjo there was also an increase from 38.62 to 71.03 while in SMP Islam Sidoarjo students increased their understanding from 38.45 to 62 . In addition, the results of student questionnaire data for each school with high and very high average categories. Through this activity students from an early age understand about tax so that they will become taxpayers who obey the law.
\end{abstract}

Keywords: interactive media, tax, student understanding

\begin{abstract}
Abstrak
Penelitian dilaksanakan dengan tujuan untuk memberikan wawasan secara langsung sejak dini kepada siswa SMP terkait pajak. Sampel penelitian yang telah dilaksanakan terdiri dari tiga sekolah, yaitu SMPN 1 Sidoarjo, SMPN 2 Sidoarjo, dan SMP Islam Sidoarjo. Siswa yang menjadi sasaran penelitian adalah siswa kelas VII dengan jumlah masing-masing siswa SMPN 1 sebanyak 40 orang, SMP N 2 sebanyak 29 orang dan SMP Islam Sidoarjo sebanyak 20 orang. Penelitian dilaksanakan dengan memberikan pelatihan kepada peserta dengan menggunakan media interaktif berbasis macromedia flash. Media interaktif berisi tentang pajak dan simulasi perhitungan pajak dan siswa dapat mensimulasi secara langsung. Metode pelaksanaan penelitian terdiri dari: (1) pendesainan media, (2) survei lapangan, (3) koordinasi ke sekolah, (4) sosialisasi, (5) pemberian pelatihan, dan (6) penyebaran angket respon siswa. Alat pengumpulan data terdiri lembar angket siswa. Hasil penelitian menunjukkan bahwa adanya peningkatan pengetahuan siswa tentang pajak sebelum dan sesudah diberikan pelatihan. Pada siswa SMPN 1 Sidoarjo terjadi peningkat dari 40,5 menjadi 78 setelah diberikan pelatihan. Pada SMPN 2 juga terjadi peningkatan dari 38,62 meingkat menjadi 71,03 sedangkan pada SMP Islam Sidoarjo peningkatan pemahaman siswa dari 38,45 menjadi 62. Selain itu, data hasil angket respon siswa setiap sekolah dengan kategori rata-rata tinggi dan sangat tinggi. Melalui kegiatan ini siswa sejak dini telah memahami tentang pajak sehingga akan menjadi wajib pajak yang mematuhi hukum.
\end{abstract}

Kata kunci: Media interaktif, pajak, Pemahaman Siswa 


\section{PENDAHULUAN}

Persaingan ekonomi global merupakan tantangan sekaligus ancaman bagi perekonomian Indonesia. Salah satu dengan diberlakukan Masyarakat Ekonomi Asia (MEA) yang menutut prekonomian Indonesia harus mampu bersaing secara Internasional. Namun, data menunjukkan bahwa pertumbuhan ekonomi di Indonesia berjalan lamban. Berdasarkan data dari badan pusat statistitik (BPS, 2016) mencatat bahwa pertumbuhan ekonomi di Indonesia pada kuartal I tahun 2016 tumbuh sebesar 5,04\%. Hal ini menunjukkan angka pencapaian di bawah target yang diberikan oleh Bank Indonesia yaitu pada tahun 2016 sebesar 5,2\% (Kemenkeu, 2016).

Selain itu, dalam memenuhi kebutuhan belanja negara pemerintah Indonesia menambah hutang. Pada tahun 2017 data menunjukkan bahwa hutang pemerintah Indonesia sebesar Rp 4.274 triliun. Hal tersebut menjadi salah satu faktor pengahambat laju pertumbuhan ekonomi. Pemerintah Indonesia juga harus menghematkan belanja negara yang termasuk dalamnya pembangunan infrastruktur dan belanja pemerintah lainnya. Dalam memenuhi kebutuhan tersebut, pemerintah Indonesia harus mengoptimalkan sumber pendapatan negara. Salah satu sumber pendapatan negara adalah pajak.

Pendapatan dari pajak merupakan sumber utama pembiayaan belanja negara. Namun, kenyataan menunjukkan bahwa pendapatan negara melalui pajak belum maksimal. Hal ini ditunjukkan dari data pendapatan pajak pada tahun 2016 hanya mencapai 81,54 persen dengan pendapatan sebesar Rp 1.105 triliun. Hasil ini belum maksimal jika dibandingkan target yang harus dicapai, Selain itu, data wajib pajak hingga tahun 2015, yang terdaftar dalam sistem administrasi Direktorat Jenderal Pajak mencapai 30.044.103 WP, yang terdiri atas 2.472.632 WP Badan, 5.239.385 WP Orang Pribadi Non Karyawan, dan 22.332.086 WP OP Karyawan. Namun, data Badan Pusat Statistik menunjukkan jumlah penduduk Indonesia yang bekerja mencapai 93,72 juta orang. Artinya baru sekitar 29,4\% dari total jumlah Orang Pribadi Pekerja dan berpenghasilan di Indonesia yang mendaftarkan diri atau terdaftar sebagai WP.

Salah satu provinsi memiliki pencapatan pajak target pendapatan yang tergolong tinggi adalah provinsi jawa timur. Data Kanwil DJP Jatim mencatatkan penerimaan pajak pada 2016 mencapai Rp 39,3 triliun. Angka ini meningkat 21,3 persen dibandingkan capaian penerimaan pajak pada 2015 yang sebesar Rp 32,4 triliun dengan target 
penerimaan pajak pada 2016 masing-masing Rp 44,2 triliun. Data ini menunjukkan bahwa pendapatan belum tercapai $100 \%$ sehingga masih diperlukan pembenahanpembenahan.

Berbagai upaya pemerintah dalam memaksimalkan pendapatan melalui pajak. Upaya tersebut yaitu dengan menerpakan tax amnesty, yaitu program pengampunan pajak. Program ini dapat meningkatkan pendapatan pajak dan wajib pajak yang memberikan laporan harta. Pada priode I, II dan III tax amnesty menunjukkan bahwa repitasi yang diperoleh negara melalui program ini sebesar Rp 1.489,9 triliun (Kemenkeu, 2017). Hal ini menunjukkan bahwa program tax amnesty dapat meningkatkan jumlah wajib pajak yang melaporkan hartanya dan meningkatkan pendapatan negara. Namun, pendapatan pajak yang ditargetkan belum tercapai secara maksimal. Menurut data Direktorat Jenderal Pajak mencatat jumlah wajib pajak yang melaporkan Surat Pemberitahuan (SPT) tahun pajak penghasilan (PPh) hingga 30 April 2016 hanya sebanyak 11,67 juta. Namun jika dibandingkan dengan target 14,6 juta SPT yang ditetapkan DJP, realisasi pelaporan SPT pada tahun ini hanya 83,3 persen atau kurang 2,93 juta SPT.

Sementara itu, tingkat kepatuhan WP badan sejauh ini belum menunjukkan perbaikan yang signifikan. Tercatat jumlah SPT yang dilaporkan WP badan hingga berakhirnya masa pelaporan SPT, 30 April 2016, hanya meningkat 1 persen, yakni dari 543.092 SPT pada 30 April 2015 menjadi 549.059 SPT. Angka itu menyumbang hanya 4,7 persen dari total SPT yang terkumpul. Data ini menunjukkan bahwa Program tax amnesty belum dapat secara maksimal menumbuhkan kesadaran masyarakat sebagai wajib pajak untuk melaporkan SPT. Kesadaran untuk patuh pajak hendaknya ditanam sejak dini pada masyarakat, sehingga tumbuh mendasar pada setiap individu.

Upaya yang dapat dilakukan oleh pemerintah adalah menumbuhkan kesadaran masyrakat untuk membayar pajak. Kesadaran terkait pentingnya pajak pada masyarakat dapat diterapkan sejak dini. Salah satunya dengan penanaman kesadaran terhadap pajak pada siswa SMP. Penanaman konsep sejak dini dapat menumbuhkan kesadaran masyarakat untuk membayar pajak. Sehingga melalui pelatihan terkait konsep pajak dapat diterapkan pada pembelajaran siswa SMP.

Dalam menyampaikan konsep pajak pada siswa SMP dapat melalui media interaktif sehingga siswa dapat dengan mudah menerima konsep yang diberikan. Salah satu media 
interaktif yang dapat digunakan adalah media berbasis macromedia flash. Melalui media ini dapat dikomunikasikan pajak dengan menyenangkan dan pada akhirnya tumbuh kesadaran terkait pajak.

\section{TINJAUAN PUSTAKA}

\section{Pajak}

Pajak adalah iuran rakyat kepada kas Negara berdasarkan Undang-undang (yang dapat dipaksakan) dengan tiada mendapat jasa timbal (kontra Prestasi) yang langsung dapat ditunjukkan dan yang digunakan untuk membayar pengeluaran umum (Mardiasmo, 2011). Pajak berfungsi sebagai: (1) anggaran (budgetair) sebagai sumber dana bagi pemerintah, untuk membiayai pengeluaran-pengeluarannya. (2) Fungsi mengatur (regulerend) sebagai alat pengatur atau melaksanakan pemerintah dalam bidang sosial ekonomi.

Dalam Surat Edaran Direktur Jenderal Pajak Nomor 103 tahun 2011 tentang petunjuk teknis tata cara penerimaan dan penglolahan Surat Pemberitahuan Tahunan yang selanjutnya disebut dengan SPT Tahunan adalah surat Pemberitahuan untuk suatu tahun pajak atau bagian tahun pajak yang meliputi SPT Tahunan Pajak Penghasilan Wajib Pajak Orang Pribadi. Fungsi Surat Pemberitahuan bagi Wajib Pajak Pajak Penghasilan adalah sebagai sarana untuk melaporkan dan mempertanggungjawabkan perhitungan jumlah pajak yang sebenarnya terhutang dan untuk melaporkan tentang: (1) pembayaran atau pelunasan pajak yang telah dilaksanakan sendiri dan atau melalui pemotongan atau pemungutan pihak lain dalam 1 (satu) tahun pajak atau bagian tahun pajak. (2) Penghasilan yang merupakan objek pajak dan atau bukan objek pajak. (3) Harta dan Kewajiban. (4) Pembayaran dari pemotong atau pemungut tentang pemotongan atau pemungutan pajak orang pribadi atau badan lain dalam 1 (satu) Masa Pajak, yang ditentukan peraturan perundangundangan perpajakan yang berlaku.

\section{Pengertian Media Pembelajaran}

Menurut Rusman (2013), media pembelajaran merupakan suatu teknologi pembawa pesan yang dapat digunakan untuk keperluan pembelajaran; media pembelajaran merupakan sarana fisik untuk menyampaikan materi pelajaran. Media pembelajaran merupakan sarana komunikasi dalam bentuk cetak maupun pandang dengar termasuk 
teknologi perangkat keras. Hal ini sejalan dengan pendapat Musfiqon (2012) bahwa media pembelajaran merupakan alat bantu yang berfungsi untuk menjelaskan sebagian dari keseluruhan program pembelajaran yang sulit dijelaskan secara verbal. Materi pembelajaran akan lebih mudah dan jelas jika dalam pembelajaran menggunakan media pembelajaran. Ini sesuai dengan fungsi media yaitu sebagai penjelas pesan.

Munadi (2013) media pembelajaran adalah segala sesuatu yang dapat menyampaikan dan menyalurkan pesan dari sumber secara terencana sehingga tercipta lingkungan belajar yang kondusif di mana penerimanya dapat melakukan proses belajar secara efisien dan efektif. Pengertian tersebut dapat disimpulkan bahwa dalam proses pembelajaran antara materi, guru, strategi, media, dan siswa menjadi rangkaian mutual yang sering mempengaruhi sesuai kedudukan masing-masing. Guru berkedudukan sebagai penyalur pesan dan siswa berkedudukan sebagai penerima pesan sedangkan media berkedudukan sebagai perantara dalam pembelajaran. media pembelajaran merupakan perantara atau penyampaian materi pembelajaran kepada siswa, karena pembelajaran yang baik tidak hanya berfokus pada penyampaian materi oleh guru ke siswa, tetapi dapat dibantu dengan media atau alat bantu pembelajaran lainnya, sehingga pembelajaran menjadi lebih kondusif dan efisien.

Penggunaan media pembelajaran dapat membantu meningkatkan pemahaman dan daya serap siswa terhadap materi pelajaran yang dipelajari. Berikut ini fungsi-fungsi dari penggunaan media pembelajaran menurut Asnawir dan Usman (2002), yaitu: (1) membantu memudahkan belajar bagi siswa, (2) memberikan pengalaman lebih nyata, (3) menarik perhatian siswa lebih besar, (4) semua indra siswa dapat diaktifkan, dan (5) lebih menarik perhatian dan minat murid dalam belajar

\section{Macromedia Flash}

Media adalah segala sesuatu yang dapat digunakan untuk menyalurkan pesan dari pengirim ke penerima sehingga dapat merangsang pikiran, perasaan, perhatian dan minat siswa (Sadiman, 1993). Hal ini juga dapat digunakan dalam menyampaikan informasi kepada publik. Salah satu media yang dapat digunakan adalah Adobe macromedia flash. Penggunaan Adobe sebagai software untuk pembuatan media pembelajaran interaktif berdasarkan pada beberapa kelebihan yang dimilikinya (Sutopo, 2003). 
Penggunaan flash tidak hanya menggabungkan elemen multimedia dengan Action Script, flash juga mempunyai kemampuan dalam membuat interaktif scripting. Macromedia flash mempunyai kelebihan dibanding program lainnya yaitu penggunaanya dapat dengan mudah dan bebas dalam berkreasi membuat animasi dengan gerakan bebas sesuai dengan adegan animasi yang dikehendaki. Berdasarkan kajian tersebut maka macro media flash dapat digunakan untuk membuat media interaktif dalam menanamkan konsep dan kesadaran tentang pajak pada siswa SMP.

\section{METODE PENELITIAN}

Metode pelaksanaan dalam penelitian ini adalah metode deskriptif kualitatif. Penelitian dilaksanakan di tiga SMP yang terdapat di Kabupaten Sidoarjo. Sekolah yang menjadi subjek penelitian adalah SMP N 1 Sidoarjo, SMP N 2 Sidoarjo, dan SMP Islam Sidoarjo. Penelitian dilaksanakan dengan memberikan pelatihan tentang pemahaman pajak kepada siswa SMP yang menjadi subjek penelitian menggunakan media interaktif berbasis macromedia flash.

\section{Metode Pelaksanaan Kegiatan}

Tahapan pelaksanaan kegiatan dalam penelitian ini digambarkan seperti bagan berikut.

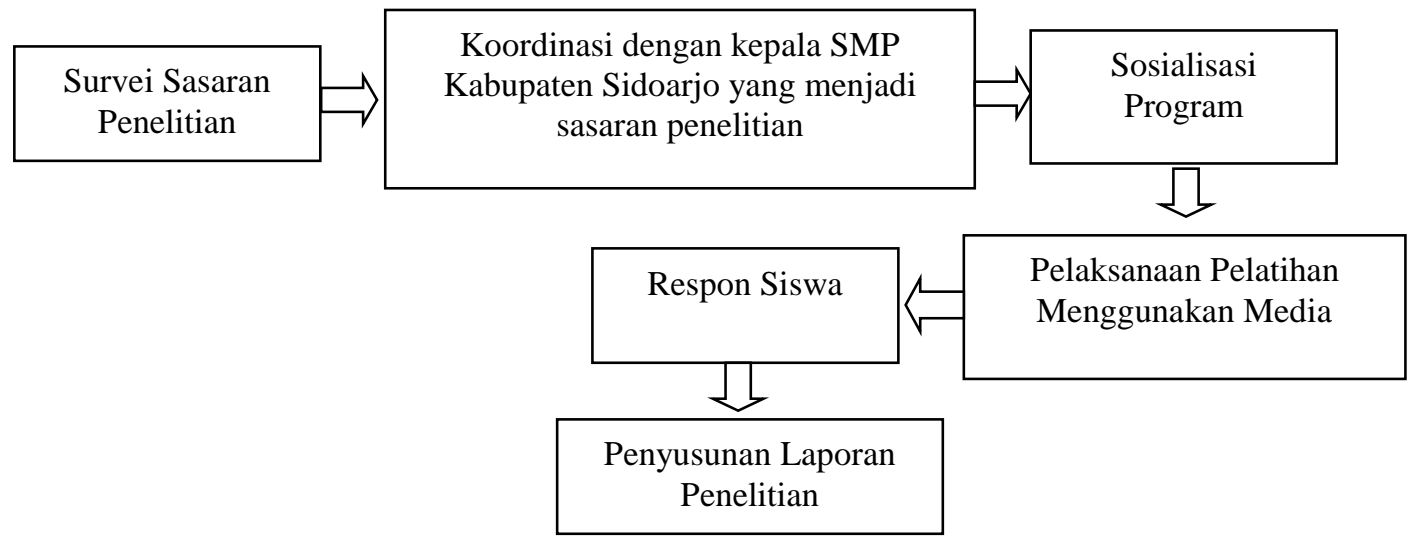

Gambar 1. Tahapan Pelaksanaan Kegiatan

\section{Metode Pembuatan Media Interaktif}

Media interaktif yang digunakan untuk memberikan konsep pajak pada siswa SMP adalah sofware mediamacro media flash. Tahapan penyusunan media interaktif pajak digambarkan pada skema berikut. 


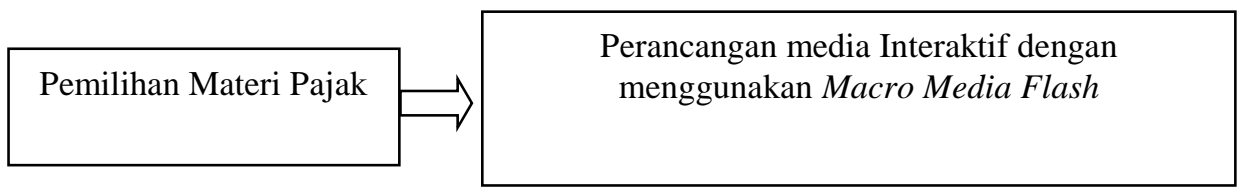

Gambar 2. Alur Penyusunan Media Pajak Interaktif

\section{Teknik Pengumpulan Data}

1) Observasi

Observasi atau pengamatan adalah suatu teknik yang dilakukan dengan cara mengadakan pengamatan secara teliti serta pencatatan secara sistematis (Arikunto, 2002). Kegiatan observasi dilaksanakan untuk mengamati aktivitas siswa dalam mengikuti kegiatan yang ditunjukkan keaktifan serta dalam media.

2) Wawancara

Wawancara adalah sebagai alat pengumpul data yang umumnya terdiri dari pertanyaan atau pernyataan yang digunakan untuk mengumpulkan informasi penelitian yang dikehendaki (Toha, 2008). Wawancara digunakan untuk mengumpulkan informasi tentang respon siswa terhadap pelatihan pajak dengan media interaktif yang sudah diberikan.

3) Dokumentasi

Metode dokumentasi dilakukan untuk memperkuat data yang diperoleh dalam observasi. Dokumen digunakan untuk memberikan gambaran secara konkret mengenai kegiatan yang dilakukan siswa dalam mengikuti pelatihan. Untuk menggambarkan suasana ketika pelaksanaan program berlangsung digunakan dokumen berupa foto.

4) Evaluasi Kegiatan

Evaluasi pelaksana kegiatan dilakukan dengan menyebarkan angket respon siswa. Angket berisi pernyataan-pernyataan tentang respon siswa terhadap kegiatan yang tela dilaksanakan. Angket berupa pernyataan yang terdiri dari lima kriteria penilaian, yaitu: (1) Sangat Tidak Setuju, (2) Tidak Setuju, (3) Cukup, (4) Setuju, (5) Sangat Setuju.

5) Penyusunan Laporan

Tahapan akhir dilakukan adalah penyusunan laporan kegiatan 


\section{Instrumen Penelitian}

Data yang digunakan dalam penelitian ini adalah data primer, yaitu data yang diperoleh secara langsung dari sasaran penelitian. Alat pengumpulan data dalam penelitian terdiri dari dua, yaitu instrumen tes dan non test. Instrumen tes berupa soal tes pengetahuan dalam bentuk pilihan ganda sebanyak 10 butir soal. Sedangkan, instrumen tes berupa kuesioner. Kriteria pilihan jawaban dalam kuesioner menggunakan skala Linkert dengan interval 1 sampai 5. Kriteria pilihan jawaban responden, yaitu: (1) Sangat Tidak Setuju (2) Tidak Setuju, (3) Cukup, (4) Setuju, dan (5) Sangat Setuju.

\section{HASIL DAN PEMBAHASAN}

\section{Deskripsi Deskripsi Pelaksanaan Penelitian}

Penelitian dilakasanakan dalam beberapa tahap, yaitu: (1) tahap survei dan koordinasi, (2) sosialisasi program, (3) pelaksanaan pelatihan, dan (4) analisis respon siswa. Deskripsi pelaksanaan penelitian diuraikan sebagai berikut.

a. Tahap Survei dan Koordinasi

Tahap survei dilaksanakan untuk mengamati sekolah secara umum yang dijadikan landasan pemilihan sekolah sasaran penelitian.

b. Sosialisasi Program

Tahap sosisalisasi dilakukan dengan berkomunikasi dengan guru terkait media yang digunakan. Pada tahap ini guru diberikan kesempatan untuk mengomentari media yang telah disusun. Tahap sosialisasi juga dilakukan dengan menginstalisasi sofware macromedia flash pada laptop guru.

c. Pelaksanaan Pelatihan

Pelatihan dilaksanakan dengan tiga tahapan, yaitu: (1) pemberian pretest pengetahuan siswa tentang pajak, (2) pelatihan (pemberian materi), (3) postest (pengetahuan dan angket respon siswa). Sebelum pelatihan dilaksanakan terlebih dahulu dilaksanakan pretest untuk mengetahui pengetahuan awal siswa tentang pajak. Pretest berupa instrumen pilihan ganda yang berjumlah sebanyak 10 butir instrumen. Setelah pretest diberikan siswa diberikan pelatihan.

Pelatihan dilaksanakan dengan menyampaikan kepada siswa tentang pengetahuan dasar tentang pajak, manfaat pajak yang digunakan oleh pemerintah untuk pembangunan. Pelatihan diberikan selama 90 menit dengan cara presentasi dan diskusi. Presentasi 
dilaksanakan selama 60 menit dengan menggunakan media belajar dengan berbantuan macromedia flash. Materi yang diberikan adalah tentang kewajiban dasar wajib pajak dalam membayar pajak. Siswa juga dibekali dengan informasi manfaat pajak dalam membangun fasilitas umum. Setelah pelatihan dilanjutkan dengan tanya jawab dan siswa dipandu untuk menghitung besar pembayaran pajak dengan memberikan contoh penghasilan, harga pembelian. Berdasarkan pengamatan peneliti sebagian siswa antusias dalam mengikuti pelatihan. Hal ini ditunjukkan dengan tingginya antusias siswa untuk menyampaikan pertanyaan. Berikut salah satu gambar siswa yang menjelaskan kepada teman-teman terkait kasus perhitungan pajak.

\section{Data Pengetahuan Siswa}

Sebelum pelaksanaan pelatihan diberikan, terlebih dahulu siswa diberikan pretest untuk mengukur kemampuan awal yang dimiliki siswa tentang pajak. Pretest dilakukan dengan memberikan soal tes pengetahuan tentang pemahaman pajak siswa. Soal berbentuk pilihan ganda yang berjumlah 10 butir soal. Pada setiap sekolah diberikan pretest sebelum pelaksanaan pelatihan. Pretest diberikan selama 30 menit. Setelah pelatihan siswa diberikan postest untuk mengukur pengetahuan siswa setelah diberikan materi pelatihan.

\section{1) Data Hasil Pretest}

Hasil tes masing-masing sekolah dideskripsikan berdasarkan nilai rata-rata yang diperoleh siswa. Gambaran rata-rata hasil tes masing-masing sekolah subjek penelitian seperti tabel berikut.

\section{Tabel 1}

Nilai pretest masing-masing sekolah subjek penelitian

\begin{tabular}{llccc}
\hline \multirow{2}{*}{ No } & \multicolumn{1}{c}{ Sekolah } & \multicolumn{3}{c}{ Data Pretest } \\
& & Rata-rata & Maks & Min \\
\hline $\mathbf{1}$ & SMP N 1 Sidoarjo & 40,50 & 60 & 10 \\
$\mathbf{2}$ & SMP N 2 Sidoarjo & 38,62 & 60 & 20 \\
$\mathbf{3}$ & SMP Islam Sidoarjo & 38,45 & 60 & 30 \\
\hline
\end{tabular}

Data di atas menunjukkan bahwa pengetahuan awal siswa tentang pajak masih rendah. Hasil pretest menunjukkan bahwa rata-rata penguasaan siswa tentang pajak secara umum sebesar 40\% yang ditunjukkan skor rata-rata sekitar 40 dari skala 100. Data hasil pretest juga menunjukkan bahwa setiap sekolah memiliki kemampaun yang 
tidak jauh berbeda. Namun, pada SMP Negeri 1 nilai terendah siswa 10 yang berarti dari 10 soal hanya satu soal yang mampu dijawab.

\section{2) Data Hasil Postest}

Setelah pelatihan atau penyampaian materi diberikan selanjutnya dilakukan selanjutnya diberikan postest. Postest dilakukan untuk mengetahui pengetahuan siswa setelah diberikan pelatihan. Soal postest diberikan sebanyak 10 soal dengan bentuk pilihan ganda. Hasil analisis postest siswa seperti tabel berikut.

Tabel 2

Nilai postest masing-masing sekolah subjekpenelitian

\begin{tabular}{crccc}
\hline \multirow{2}{*}{ No } & \multirow{2}{*}{ Sekolah } & \multicolumn{3}{c}{ Data Postest } \\
\cline { 3 - 5 } & & Rata-rata & Maks & Min \\
\hline $\mathbf{1}$ & SMP N 1 & 78 & 90 & 60 \\
$\mathbf{2}$ & SMP N 2 & 71,03 & 90 & 60 \\
$\mathbf{3}$ & SMP Islam & 62 & 90 & 30 \\
\hline
\end{tabular}

Data hasil postest di atas menunjukkan rata-rata nilai siswa lebih dari 60 dengan nilai maksimal 90 dan nilai minimum 60 kecuali pada SMP Islam dengan nilai minimum 30. Data pada tabel di atas menunjukkan bahwa nilai tertinggi terdapat pada siswa SMP Negeri 1 Sidoarjo dengan nilai sebesar 78 dan terendah terdapat pada SMP Islam dengan nilai 62.

\section{3) Peningkatan Pengetahuan Siswa}

Data pengetahuan siswa setelah melaksanakan pelatihan terjadi peningkatan yang signifikan. Peningkatan pemahaman siswa tentang pajak terjadi pada setiap sekolah. Gambaran peningkatan pengetahuan siswa setiap sekolah seperti pada gambar berikut.

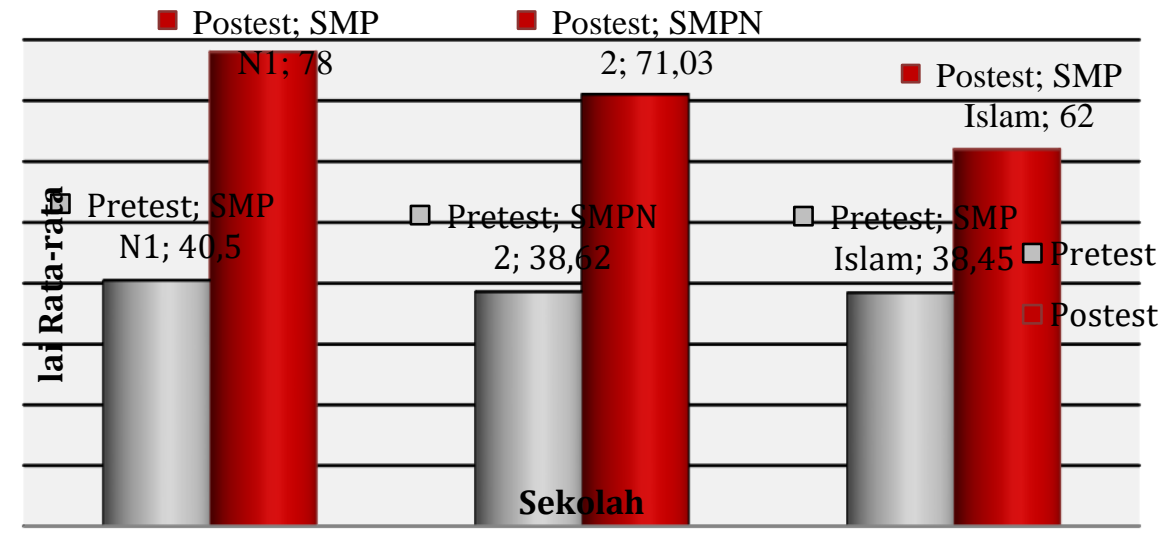

Gambar 3. Peningkatan Pemahaman siswa 
Grafik di atas menunjukkan bahwa terjadi peningkatan yang signifikan antara hasil pretest dan postest pemahaman siswa. Sebelum diberikan pelatihan rata-rata nilai siswa hanya berkisar 40 sedangkan setelah diberikan pelatihan mencapai 70. Pada SMP N 1 mencapai 78 dengan peningkatan hampir 50\% dari nilai awal. Pada SMP N 2 Sidoarjo juga terjadi peningkatan dari 38,62 menjadi 71,03 setelah diberikan pelatihan. Sedangkan pada SMP Islam Sidaorjo meningkat dari 38,45 menjadi 62.

\section{a. Data Hasil Respon Siswa}

Pengamatan juga dilakukan pada respon siswa setelah diberikan pelatihan tentang pajak. Data respon siswa diperoleh dari kuesioner yang disebarkan setelah pemberian pelatihan. Kuesioner terdidir dari 10 item pernyataan dengan pilihan jawaban skala Linkert, yaitu: (1) sangat tidak setuju, (2) Tidak setuju, (3) Cukup, (4) Setuju, dan (5) sangat Setuju. Data hasil respon siswa berupa data kuantitatif dari masing-masing penilaian responden (siswa) pada setiap item pernyataan. Data dideskripsikan berdasarkan hasil kuesioner yang diperoleh dari 90 siswa dari tiga sekolah di Kabupaten Sidaorjo. Data hasil penelitian ini dideskripsikan berdasarkan kisaran skor masingmasing sekolah. Adapun deskripsi hasil respon siswa setelah mengikuti pelatihan masingmasing sekolah diuraikan sebagai berikut.

\section{1) Data Respon Siswa SMP Negeri 1 Sidoarjo}

Jumlah siswa peserta pelatihan pada SMP Negeri 1 Sidoarjo sebanyak 40 orang siswa. Setiap siswa yang telah mengikuti pelatihan diberikan penlialian respon dengan mengggunakan angket. Hasil respon berdasarkan hasil analisis angket seperti tabel berikut.

Tabel 3

Distribusi Respon Siswa SMP N 1 Sidoarjo

\begin{tabular}{|c|c|c|c|}
\hline No & Pernyataan Variabel & Rata-rata & Kategori \\
\hline 1 & $\begin{array}{l}\text { Saya menyadari bahwa pajak merupakan sumber } \\
\text { penerimaan negara terbesar }\end{array}$ & 3,90 & Tinggi \\
\hline 2 & $\begin{array}{l}\text { Saya menyadari bahwa membayar pajak merupakan } \\
\text { kewajiban mutlak setiap warga negara dan diatur oleh } \\
\text { Undang-Undang }\end{array}$ & 4,26 & $\begin{array}{l}\text { Sangat } \\
\text { Tinggi }\end{array}$ \\
\hline 3 & $\begin{array}{l}\text { Saya menyadari bahwa setiap warga harus melapirkan } \\
\text { harta secara benar }\end{array}$ & 3,86 & Tinggi \\
\hline 4 & $\begin{array}{l}\text { Dana pajak sepenuhnya dapat digunakan untuk } \\
\text { membiayai belanja negara }\end{array}$ & 3,70 & Cukup \\
\hline 5 & $\begin{array}{l}\text { Setiap warga yang memiliki kendaraan bermotor wajib } \\
\text { membayar pajak }\end{array}$ & 4,27 & $\begin{array}{l}\text { Sangat } \\
\text { Tinggi }\end{array}$ \\
\hline 6 & $\begin{array}{l}\text { Saya menyadari bahwa setiap orang yang mendapatkan } \\
\text { penghasilan di Indonesia dan memenuhi syarat, wajib } \\
\text { dikenai pajak penghasilan dan harus memenuhi kewajiban } \\
\text { perpajakannya }\end{array}$ & 4,26 & $\begin{array}{l}\text { Sangat } \\
\text { Tinggi }\end{array}$ \\
\hline
\end{tabular}




\begin{tabular}{clcc}
\hline $\mathbf{7}$ & $\begin{array}{l}\text { Saya menyadari bahwa menunda dan mengurangi jumlah } \\
\text { pajak yang seharusnya dibayar, dapat merugikan negara }\end{array}$ & 4,05 & Tinggi \\
$\mathbf{8}$ & $\begin{array}{l}\text { Saya menyadari bahwa membayar pajak merupakan salah } \\
\text { satu bentuk partisipasi dan peran saya dalam } \\
\text { pembangunan negara }\end{array}$ & 4,24 & $\begin{array}{c}\text { Sangat } \\
\text { Tinggi }\end{array}$ \\
$\mathbf{9} \begin{array}{l}\text { Saya membayar dan melaporkan pajak penghasilan sesuai } \\
\text { dengan kondisi penghasilan dari usaha saya yang }\end{array}$ & 3,92 & Tinggi \\
$\begin{array}{l}\text { sebenarnya karena dorongan hati nurani } \\
\text { Sanksi pajak sangat diperlukan untuk menciptakan } \\
\text { kedisiplinan setiap wajib pajak }\end{array}$ & 4,18 & Tinggi \\
\hline Rata-rata Total & $\mathbf{4 , 0 7}$ & Tinggi \\
\hline
\end{tabular}

Data di atas menunjukka bahwa pada SMP Negeri 1 rata-rata total respon siswa memiliki kategori tinggi dengan skor rata-rata 4,07. Sedangkan skor rata-rata tertinggi terdapat pada item 5 dengan skor rata-rata 4,27 (kategori sangat tinggi). Pernyataan yang memiliki skor rata-rata tertinggi adalah Setiap warga yang memiliki kendaraan bermotor wajib membayar pajak. Sedangkan rata-rata terendah terdapat pada pernyataan "Dana pajak sepenuhnya dapat digunakan untuk membiayai belanja negara" dengan skor ratarata 3,70 (kategori cukup). Hal ini menunjuukan bahwa pemahaman siswa tentang penggunaan pendapatan dari pajak masih ragu-ragu dalam menjawab. Hal ini juga menunjukkan perlunya penekanan pemahaman kepada siswa tentang manfaat dan penggunaan pendapatan pajak.

\section{2) Data Respon Siswa SMPN 2 Sidoarjo}

Data hasil analisis angket respon siswa pada SMP N 2 Sidoarjo seperti pada tabel berikut.

\section{Tabel 4}

Distribusi Respon Siswa SMP N 2 Sidoarjo

\begin{tabular}{clcc}
\hline No & \multicolumn{1}{c}{ Pernyataan Variabel } & Rata-rata & Kategori \\
\hline $\mathbf{1}$ & $\begin{array}{l}\text { Saya menyadari bahwa pajak merupakan sumber } \\
\text { penerimaan negara terbesar }\end{array}$ & 4,48 & Sangat Tinggi \\
$\mathbf{2}$ & $\begin{array}{l}\text { Saya menyadari bahwa membayar pajak merupakan } \\
\text { kewajiban mutlak setiap warga negara dan diatur oleh }\end{array}$ & 4,66 & Sangat Tinggi \\
$\mathbf{3}$ & $\begin{array}{l}\text { Undang-Undang } \\
\text { Saya menyadari bahwa setiap warga harus melapirkan } \\
\text { harta secara benar }\end{array}$ & 4,14 & Tinggi \\
$\mathbf{4}$ & $\begin{array}{l}\text { Dana pajak sepenuhnya dapat digunakan untuk } \\
\text { membiayai belanja negara }\end{array}$ & 3,72 & Tinggi \\
$\mathbf{5} \quad \begin{array}{l}\text { Setiap warga yang memiliki kendaraan bermotor wajib } \\
\text { membayar pajak } \\
\text { Saya menyadari bahwa setiap orang yang mendapatkan } \\
\text { penghasilan di Indonesia dan memenuhi syarat, wajib } \\
\text { dikenai pajak penghasilan dan harus memenuhi } \\
\text { kewajiban perpajakannya } \\
\text { Saya menyadari bahwa menunda dan mengurangi } \\
\text { jumlah pajak yang seharusnya dibayar, dapat merugikan } \\
\text { negara }\end{array}$ & 4,17 & Tinggi \\
\end{tabular}


8 Saya menyadari bahwa membayar pajak merupakan salah satu bentuk partisipasi dan peran saya dalam pembangunan negara

9 Saya membayar dan melaporkan pajak penghasilan sesuai dengan kondisi penghasilan dari usaha saya yang sebenarnya karena dorongan hati nurani

10 Sanksi pajak sangat diperlukan untuk menciptakan kedisiplinan setiap wajib pajak
4,31 Sangat Tinggi

3,97 Tinggi

4,38 Sangat Tinggi 4,22 Sangat Tinggi

Data di atas menunjukka bahwa pada SMP Negeri 2 rata-rata total respon siswa memiliki kategori sangat tinggi dengan skor rata-rata 4,22. Sedangkan skor rata-rata tertinggi terdapat pada item 2 dengan skor rata-rata 4,66 (kategori sangat tinggi) dengan pernyataan "Saya menyadari bahwa membayar pajak merupakan kewajiban mutlak setiap warga negara dan diatur oleh Undang-Undang". Hal ini menunjukkan kesadaran siswa jika menjadi wajib pajak telah tinggi. Selanjutnya skor terendah terdapat pada item 4 dengan pernyataan "dana pajak sepenuhnya dapat digunakan untuk membiayai belanja negara" dengan skor rata-rata 4,28 (kategori tinggi). Hal ini menunjuukan bahwa pemahaman siswa tentang penggunaan pendapatan dari pajak masih perlu ditingkatkan.

\section{3) Data Respon Siswa SMP Islam Sidoarjo}

Data hasil analisis angket respon siswa pada SMP Islam Sidoarjo seperti pada tabel berikut.

\section{Tabel 5}

Distribusi Respon Siswa SMP Islam Sidoarjo

\begin{tabular}{|c|c|c|c|}
\hline No & Pernyataan Variabel & Rata-rata & Kategori \\
\hline 1 & $\begin{array}{l}\text { Saya menyadari bahwa pajak merupakan sumber } \\
\text { penerimaan negara terbesar }\end{array}$ & 3,60 & Tinggi \\
\hline 2 & $\begin{array}{l}\text { Saya menyadari bahwa membayar pajak merupakan } \\
\text { kewajiban mutlak setiap warga negara dan diatur oleh } \\
\text { Undang-Undang }\end{array}$ & 3,90 & Tinggi \\
\hline 3 & $\begin{array}{l}\text { Saya menyadari bahwa setiap warga harus melapirkan harta } \\
\text { secara benar }\end{array}$ & 3,50 & Tinggi \\
\hline 4 & $\begin{array}{l}\text { Dana pajak sepenuhnya dapat digunakan untuk membiayai } \\
\text { belanja negara }\end{array}$ & 2,80 & Cukup \\
\hline 5 & $\begin{array}{l}\text { Setiap warga yang memiliki kendaraan bermotor wajib } \\
\text { membayar pajak }\end{array}$ & 4,20 & Tinggi \\
\hline 6 & $\begin{array}{l}\text { Saya menyadari bahwa setiap orang yang mendapatkan } \\
\text { penghasilan di Indonesia dan memenuhi syarat, wajib } \\
\text { dikenai pajak penghasilan dan harus memenuhi kewajiban } \\
\text { perpajakannya }\end{array}$ & 3,90 & Tinggi \\
\hline 7 & $\begin{array}{l}\text { Saya menyadari bahwa menunda dan mengurangi jumlah } \\
\text { pajak yang seharusnya dibayar, dapat merugikan negara }\end{array}$ & 3,40 & Tinggi \\
\hline 8 & $\begin{array}{l}\text { Saya menyadari bahwa membayar pajak merupakan salah } \\
\text { satu bentuk partisipasi dan peran saya dalam pembangunan } \\
\text { negara }\end{array}$ & 3,80 & Tinggi \\
\hline
\end{tabular}




\begin{tabular}{clllc}
\hline 9 & $\begin{array}{l}\text { Saya membayar dan melaporkan pajak penghasilan sesuai } \\
\text { dengan kondisi penghasilan dari usaha saya yang }\end{array}$ & 3,80 & Tinggi \\
$\begin{array}{l}\text { sebenarnya karena dorongan hati nurani } \\
\mathbf{1 0}\end{array}$ & $\begin{array}{l}\text { Sanksi pajak sangat diperlukan untuk menciptakan } \\
\text { kedisiplinan setiap wajib pajak } \\
\text { Rata-rata Total }\end{array}$ & 4,00 & Tinggi \\
\hline
\end{tabular}

Data di atas menunjukkan bahwa rata-rata total respon siswa memiliki kategori tinggi dengan skor rata-rata 3,69. Skor rata-rata tertinggi terdapat pada item 2 dengan skor rata-rata 4,00 (kategori tinggi) dengan pernyataan "Sanksi pajak sangat diperlukan untuk menciptakan kedisiplinan setiap wajib pajak". Hal ini menunjukkan kesadaran siswa tentang sanksi pajak telah tinggi. Selanjutnya skor terendah terdapat pada item 4 dengan pernyataan "dana pajak sepenuhnya dapat digunakan untuk membiayai belanja negara" dengan skor rata-rata 2,80 (kategori cukup). Hal ini menunjuukan bahwa pemahaman siswa tentang penggunaan pendapatan dari pajak masih perlu ditingkatkan.

\section{b. Analisis Perbandingan Pemahaman Sebelum dan Sesudah Pelatihan}

Hasil analisis menunjukkan terdapat perbedaan rata-rata pemahaman siswa tentang pajak sebelum dan sesudah pelatihan. Untuk menganalisis perbedaan tersebut secara statistik dilakukan dengan analisis uji t. Adapun hipotesis yang diuji sebagai berikut.

$\mathrm{H}_{0}$ : Tidak terdapat perbedaan signifikan antara pemahaman siswa sebelum dan sesudah diberikan pelatihan.

$\mathrm{H}_{1}$ : terdapat perbedaan signifikan antara pemahaman siswa sebelum dan sesudah diberikan pelatihan

Dengan kriteria pengujian : Jika $t_{\text {hitung }}>t_{\text {tabel }}$ dan taraf signifikan $<\alpha=0,05$ maka $\mathrm{H}_{0}$ diterima. jika $-\mathrm{t}_{\text {tabel }}<\mathrm{t}_{\text {hitung }}<$ tabel dan taraf signifikan $>\alpha=0,05$ maka $\mathrm{H}_{0}$ ditolak. Hasil uji t pemahaman siswa sebelum dan sesudah diberikan pelatihan ditunjukkan tabel berikut :

Tabel 6 Data Hasil Uji T

\begin{tabular}{|c|c|c|c|c|c|c|c|}
\hline \multirow[b]{3}{*}{$\begin{array}{l}\text { Pair } \\
1\end{array}$} & \multirow[b]{3}{*}{$\begin{array}{l}\text { Pretest - } \\
\text { Postest }\end{array}$} & \multicolumn{3}{|c|}{ Paired Differences } & \multirow[t]{2}{*}{$\mathrm{t}$} & \multirow[t]{2}{*}{$\overline{d f}$} & \multirow{2}{*}{$\begin{array}{l}\text { Sig. (2- } \\
\text { tailed) }\end{array}$} \\
\hline & & Mean & Std. & Std. Error & & & \\
\hline & & 32,70 & 16,351 & 1,73324 & 18,87 & 88 & 000 \\
\hline
\end{tabular}

Tabel uji t tersebut menunjukkan pada pemahaman siswa sebelum dan sesudah pelatihan dengan nilai $t_{\text {hitung }}>\mathrm{t}_{\text {tabel }}$ yaitu 18,87 dan signifikan $0,000<0,005$. Dari hasil tersebut menunjukkan adanya perbedaan yang signifikan antara pemahaman siswa sebelum dan sesudah pemberian pelatihan pajak. 


\section{KESIMPULAN DAN SARAN}

\section{a. Simpulan}

Pelatihan pemahaman pajak menggunakan media berbasis macromedia flash dilaksanakan di Tiga Sekolah, yaitu SMP Negeri 1 Sidoarjo, SMP Negeri 2 Sidoarjo dan SMP Islam Sidoarjo. Hasil penelitian menunjukkan bahwa adanya peningkatan pemahaman siswa tentang pajak sebelum dan sesudah diberikan pelatihan. Pada siswa SMPN 1 Sidoarjo terjadi peningkat dari rata-rata 40,5 menjadi 78. Pada SMPN 2 juga terjadi peningkatan dari 38,62 meingkat menjadi 71,03 sedangkan pada SMP Islam Sidoarjo peningkatan pengetahuan dari 38,45 menjadi 62. Selain itu, data hasil angket respon siswa setiap sekolah dengan kategori rata-rata tinggi. Hasil analisis uji $\mathrm{t}$ menunjukkan adanya perbedaan pemahaman siswa sebelum dan sesudah diberikan pelatihan dengan ditunjukkan nilai signifikansi uji t sebesar 0,00<0,005. Melalui kegiatan ini siswa sejak dini telah memahami tentang pajak sehingga akan menjadi wajib pajak yang mematuhi hukum

\section{b. Saran}

Berdasarkan pelaksanaan pelatihan pemahaman pajak siswa menggunakan media pembelajaran berbasisis macromedia flash, dapat disarankan hal-hal sebagai berikut:

1) Guru dapat menambahkan materi tentang pajak secara umum agar pemahaman siswa tentang pajak lebih luas

2) Guru dapat menambah latihan-latihan atau perhitungan pajak dalam kehidupan

3) Pemanfaatan media berbasis komputer dapat dikembangkan secara online sehingga mudah diakses oleh siswa

\section{DAFTAR PUSTAKA}

Arikunto, S. 2002. Manajemen penelitian. Jakarta: Rineka Cipta

Asnawir dan Usman. 2002. Media Pembelajaran. Jakarta: Ciputat. Pers

Direktorat Jenderal Pajak. 2016. Laporan pendapatan pajak negara

Kementerian Keuangan Republik Indonesia. 2017. Anggaran Pendapatan dan Belanja Negara (APBN).

Mardiasmo.2011. Perpajakan Edisi Revisi. Yogyakarta: Penerbit Andi 
Munadi, Yudhi. 2013. Media Pembelajaran. Jakarta: Referensi

Musfiqon. 2012. Pengembangan Media Belajar Dan Sumber Belajar. Jakarta : Prestasi Pustakakarya

Pemerintah RI. 2011. Surat Edaran Direktur Jenderal Pajak Nomor 103 tahun 2011

Rusman. 2013. Model-Model Pembelajaran. Jakarta: Raja Grafindo Persada

Sutopo. 2003. Multimedia Interaktif dan Flash. Yogyakarta: PT Graha Ilmu

Toha, M. 2008. Metode penelitian. Yogyakarta: Media Pressindo 